\title{
Functional Capacity Improvement Related to Inflammatory Marker Reduction After Phase II Cardiac Rehabilitation Program in Post- revascularization Coronary Artery Disease Patients
}

Badai B. Tiksnadi ${ }^{1,}{ }^{*}$, Melisa Aziz'1, Manda S. Chesario', Mochamad Renaldi',Ahmad Triadi', Sunaryo B.

Sastradimaja ${ }^{2}$, Augustine Purnomowati ${ }^{1}$, Toni M. Aprami ${ }^{1}$

\footnotetext{
${ }^{1}$ Department of Cardiology and Vascular Medicine, Faculty of Medicine, Universitas Padjadjaran, Bandung, Indonesia ${ }^{2}$ Department of Physical and Medical Rehabilitation, Faculty of Medicine, Universitas Padjadjaran, Bandung, Indonesia

${ }^{*}$ Corresponding author:

Badai Bhatara Tiksnadi MD.- email: tiksnadi_badai@yahoo.com

Address: Departemen Kardiologi dan Kedokteran Vaskular, Gedung Rumah Sakit Pendidikan Fakultas Kedokteran Universitas Padjadjaran, Jalan Eyckman Lantai 4 No. 38, Bandung 40161.
}

Manuscript submitted: August 23, 2018; Revised and accepted: December 16, 2018

\section{ABSTRACT}

Background: Improved functional capacity (FC) and inflammatory marker reduction is a good prognostic factor in post-revascularization cardiac patients. However, there is still limited study investigated association of functional capacity and inflammatory marker after cardiac rehabilitation program. We studied the effects of cardiac rehabilitation (CR) program in the improvement of FC and high-sensitive-C Reactive Protein (hs-CRP) reduction and association between those variables.

Methods: This was quasi experimental study in post-revascularization CAD patients who attended phase II CR program at CR gymnasium, Dr. Hasan Sadikin General Hospital, Bandung, from October 2014 to May 2015. The CR program included additional education sessions and consistently strict program intensity on $50-80 \%$ heart rate reserve based on formula and Borg scale 11 to 15 . Functional capacity and hsCRP were measured before and after the program. Functional capacity was assessed by maximal treadmill test through indirect $\mathrm{VO}_{2}$ max measurement.

Results: A total of 37 patients aged $56.05 \pm 7.3$ years old were analyzed in this study. They consisted mainly of men $(81.1 \%)$ which $78.4 \%$ of them underwent percutaneous coronary intervention $(\mathrm{PCl})$. Our study revealed significant $\mathrm{FC}$ improvement after completion of this newly-modified CR program from an average of 6.76 to $8.68 \mathrm{METs}$ $(28.4 \%)(p<0.001)$. Hs-CRP reduction was also occurred from mean of $0.49 \mathrm{mg} / \mathrm{L}$ to $0.20 \mathrm{mg} / \mathrm{L}(59.2 \%)$ of log hs-CRP level $(p=0.005)$. Linear regression analysis showed the improvement of fitness was associated with baseline FC $(p<0.001)$ and reduction of hs-CRP was associated with baseline hs-CRP $(p<0.001)$, and not influenced by age, gender, ejection fraction and type of procedure. There is moderate correlation $\left(r_{s}=\right.$ $0.636, p<0.001$ ) between functional capacity improvement and hs-CRP reduction. Each 1 METs improvement can reduce $9.317 \mathrm{mg} / \mathrm{L}$ of transformed hs-CRP level $(p=0.006$, $95 \% \mathrm{Cl} 2.942,15.693)$.

Conclusions: CR program significantly increased functional capacity and reduce hsCRP level in post-revascularization CAD patient, and more prominent in a patient with low baseline functional capacity and high hs-CRP level. Functional capacity improvement and hs-CRP reduction were moderately correlated.

Keywords: cardiac rehabilitation program; functional capacity; hs-CRP 


\section{INTISARI}

Latar belakang: Peningkatan kapasitas fungsional dan penurunan penanda inflamasi merupakan suatu faktor prognostik yang baik pada pasien pasca revaskularisasi jantung. Namun studi mengenai hubungan antara kapasitas fungsional dan penanda inflamasi masih terbatas. Penelitian ini bertujuan mempelajari pengaruh program rehabilitasi jantung terhadap perbaikan kapasitas funsional dan penurunan highsensitive-C Reactive Protein (hs-CRP) serta asosiasi di antara kedua variable tersebut. Metode: Studi eksperimental-kuasi dilakukan pada pasien penderita penyakit arteri koroner pasca revaskularisasi yang menjalani program rehabilitasi jantung fase II di pusat kebugaran rehabilitasi jantung, Rumah Sakit Umum Pusat Dr. Hasan Sadikin, Bandung dari Bulan Oktober 2014 sampai Mei 2015. Program baru ini meliputi sesi edukasi tambahan dan secara konsisten menggunakan intensitas latihan 50-80\% dari cadangan laju denyut jantung berdasarkan formula dan skala Borg 11 sampai 15. Kapasitas fungsional dan kadar hs-CRP dalam darah diukur sebelum dan setelah menjalani program. Kapasitas fungsional dinilai dengan menggunakan tes ban berjalan maksimal, melalui pengukuran $\mathrm{VO}_{2}$ max secara tidak langsung.

Hasil: Sebanyak 37 pasien dianalisis dalam studi ini. Sebagian besar subjek $(81.1 \%)$ berjenis kelamin laki-laki, dengan usia rata-rata $56.05 \pm 7.3$ tahun dimana $78.4 \%$ subjek merupakan pasien pasca intervensi koroner perkutan. Penelitian kami menunjukkan bahwa kapasitas fungsional meningkat secara bermakna dari rata-rata 6.76 METs menjadi 8.68 METs (peningkatan sebanyak 28.4\%) dengan $p<0.001$ setelah menjalani program baru rehabilitasi jantung termodifikasi. Penurunan hs-CRP juga terjadi dari rata-rata nilai log hs-CRP $0.49 \mathrm{mg} / \mathrm{L}$ ke $0.20 \mathrm{mg} / \mathrm{L}(59.2 \%)(p=0.005)$. Hasil analisis regresi linear menunjukkan bahwa perbaikan dari kebugaran berkaitan dengan kapasitas fungsional awal $(p<0.001)$, dan penurunan hs-CRP berkaitan dengan kadar log hs-CRP awal $(p<0.001)$, dan tidak dipengaruhi oleh usia, jenis kelamin, fraksi ejeksi dan tipe prosedur. Terdapat korelasi derajat sedang $\left(r_{s}=0.636\right.$, $\mathrm{p}<0.001)$ antara perbaikan kapasitas fungsional dan penurunan hs-CRP. Setiap perbaikan 1 METs dapat menurunkan $9.317 \mathrm{mg} / \mathrm{L}$ kadar hs-CRP yang telah ditransformasi ( $p=0.006,95 \% \mathrm{Cl} 2.942,15.693)$.

Kesimpulan: Program baru rehabilitasi jantung meningkatkan kapasitas fungsional dan menurunkan kadar hs-CRP secara bermakna pada pasien penyakit arteri koroner pasca revaskularisasi, dimana hal tersebut lebih terlihat jelas pada pasien dengan kapasitas fungsional awal yang rendah dan kadar hs-CRP awal yang tinggi. Terdapat korelasi yang bersifat moderat antara perbaikan kapasitas fungsional dan penurunan hs-CRP.

\section{INTRODUCTION}

Cardiovascular disease has become a global health problem in worldwide countries, including Indonesia. ${ }^{1-3}$ Advances in technology and medicine has brought better survival rate in coronary artery disease patients in the last decades. ${ }^{4}$ Despite the fact that reduction of coronary artery disease (CAD) morbidity and mortality by improvement in coronary artery bypass graft (CABG) and percutaneous coronary intervention
(PCI) technique, the rate of myocardial reinfarction and CAD-related rehospitalization are still high. In the United States, overall 30-day readmission rate was $14.5 \%$ of which $8.3 \%$ caused by cardiac disease, and post-acute myocardial infarction 90-day readmission rate was $24 \%$. It was estimated to cost country about $\$ 1.1$ billion for 30 -day readmissions. ${ }^{5}$ To overcome this situation, cardiac rehabilitation (CR) as secondary prevention program needs to be optimized. 
Improved functional capacity (FC) is a better prognostic factor in post-revascularization cardiac patients. It is proven to improve quality of life, decrease cardiovascular event and reduce mortality. ${ }^{6}$ Improvement of FC could be achieved by aerobic exercise as its cardioprotection and decrease post-stenting late lumen loss effects, contribute to decreasing in restenosis rate. $^{7}$ Aerobic exercise increased $33 \%$ of $\mathrm{FC}$ and $16 \%$ of maximal oxygen intake $\left(\mathrm{VO}_{2} \max \right){ }^{6}$ Myers et al. showed every improvement of 1 metabolic equivalents (METs) in functional capacity reduced $12 \%$ of mortality risk in cardiovascular patients. ${ }^{8}$

Inflammation parameter is highly correlated with atherosclerosis process and could accurately predict future cardiovascular event in healthy population. ${ }^{9-11}$ Inflammation parameter is also used as successful of treatment and secondary prevention indicator. ${ }^{12}$ Several studies in post-cardiac rehabilitation among CAD patients in various population showed significant reduction of $0.7-2.1 \mathrm{mg} / \mathrm{L}$ in inflammatory mediators level. ${ }^{13-15}$

Inflammatory marker such as high-sensitive-C Reactive Protein (hsCRP) level is reported inversely associated with FC in normal population as well as patients with CAD. ${ }^{16-18}$ Prognostic impact of FC improvement in mortality was thought mediated by its inflammation reduction effect. ${ }^{18}$ However,there is still limited study investigated association of $\mathrm{FC}$ and inflammatory marker after CR program in post revascularization CAD patient. The aim of this study was to investigate the effects CRprogram in improvement of FC and hs CRP level and their association after CR program.

\section{METHODS}

\section{Ethical Statement}

All subjects were informed about the possible risks of the investigation before giving written informed consent to participate. All procedures were through evaluation and approval by Dr. Hasan Sadikin General Hospital research ethic committee with ethical clearance number LB.04.01/A05/EC/442/X/2014.

\section{Subject Recruitment}

Subjects were recruited consecutively from cardiac prevention and rehabilitation/cardio-respiration clinic Dr.Hasan Sadikin General Hospital, Bandung, Indonesia. All postrevascularization CAD patients were screened with initial assessment protocol consisted of history taking, physical examination, baseline data (echocardiography, angiography, and laboratory) collecting, assessment of indication and contraindication for rehabilitation program, as well as risk stratification based on American Association of Cardiovascular and Pulmonary Rehabilitation (AACVPR) criteria $^{19}$ (Figure 1).

Patients enrolled in this study included patients who (1) underwent cardiac revascularization (CABG or $\mathrm{PCI}$ ); (2) attended phase II CR program at CR gymnastium, Dr. Hasan Sadikin General Hospital, Bandung, from October 2014 until May 2015; (3) absence of contraindication for rehabilitation exercise; (4) volunteered to attend for at least two sessions a week until a total of twelve sessions; (5) absence of cardiac revascularization schedulewithin the next six weeks; (6) absence of neuromusculoskeletal/ physiciatry comorbidity which able to disrupt communication, exercise capability, and maximal functional capacity assesment; (7) absence of autoimmune or inflammatory disease which able todisrupt inflammation parameter result; and (8) volunteered to be participant and signed an informed consent.

\section{Functional Capacity Examination}

All subjects underwent maximal exercise stress test based on the 
recommendation from European Association for Cardiovascular Prevention and Rehabilitation (EACPR), American Association of Cardiovascular and Pulmonary Rehabilitation (AACVPR), Canadian Association of Cardiac Rehabilitation $(\mathrm{CACR})^{19}$, European Society of Cardiology $^{20}$ and American Heart Association $^{21}$ cardiac rehabilitation program. Exercise stress test using GE T-2100 treadmill without respiratory gas analysis with Bruce or modified Bruce protocol, adjusted to patient ability estimation based on 6-minutes walk test result at phase I CR program. The speed and inclination of treadmill test were increased every 3 minutes until subject felt exhausted (Borg scale above 17). Functional capacity was determined based on indirect $\mathrm{VO}_{2}$ max estimation by converting treadmill test duration into METs.

\section{Cardiac rehabilitation program}

Duration of the program was four to eight weeks (twice weekly), consisted of 6 to 12 education sessions and supervised aerobic exercises (using ergocycle and treadmill). Aerobic exercise was held for 30 minutes of moderate intensity $[50-80 \%$ heart rate reserve (from entrance maximal treadmill test) and Borg scale 11-15] with continuous training method. The subject complaint, blood pressure, pulse, and oxygen saturation were recorded. The home exercise program was also prescribed. Furthermore, each patient was given personal health education included cardiac anatomy, exercise, sexual activity and healthy diet with educational video program.

hs-CR

Venous blood samples were collected and examined in clinical pathology department Dr. Hasan Sadikin Hospital. The quantitative measurement of CRP was performed using a particle enhanced immuneturbidimetric assay integrated with Cobas C 311 automated chemistry analyzer (Indianapolis, USA). Human
CRP agglutinates with latex particles coated with monoclonal anti-CRP antibodies. The precipitate was determined turbidimetrically, samples dispensed and all processes done automatically and concentration obtained for each sample.Lower detection limit of hs-CRP was 0.15 $\mathrm{mg} / \mathrm{L}(1.43 \mathrm{nmol} / \mathrm{L}, 0.015 \mathrm{mg} / \mathrm{dL})$ with functional sensitivity $0.3 \mathrm{mg} / \mathrm{L} \quad(2.96$ $\mathrm{nmol} / \mathrm{L}, 0.03 \mathrm{mg} / \mathrm{dL}){ }^{22}$

Drop out

All subjects who (1) absence from exercises for consecutive three weeks; (2) attended exercise less than six times in eight weeks; (3) had serious exercise complication; and (4) had incomplete data; were dropped out from the study.

\section{Statistical Analysis}

This was a quasi experimental study. The differences between FC and hs-CRP before and after the program were analyzed with paired t-test using SPSS 21.0. Related factors were examined with Spearman's /Pearson's correlation, Mann- Whitney U/ independent t-test analysis and Fisher's exact test, based on type and distribution of data. Multivariate analysis was performed to evaluate significance of baseline FC and baseline hs-CRP as predictors of FC improvement and hs-CRP reduction after CR program. All $P$-values $<0.05$ were considered statistically significant.

\section{RESULT}

Forty-four patients were enrolled in this study with seven of them were excluded (four drop-outs, one loss to follow-up and two incomplete procedures). A total of 37 subjects were analyzed for functional capacity improvement. Mean age of subject was $56.05 \pm 7.3$ years old, range $37-73$ years old. Thirty subjects $(81.1 \%)$ were male, seven subjects $(18.9 \%)$ were female. Majority of our subjects had a minimum of senior high school level of education $(70.3 \%)$. 


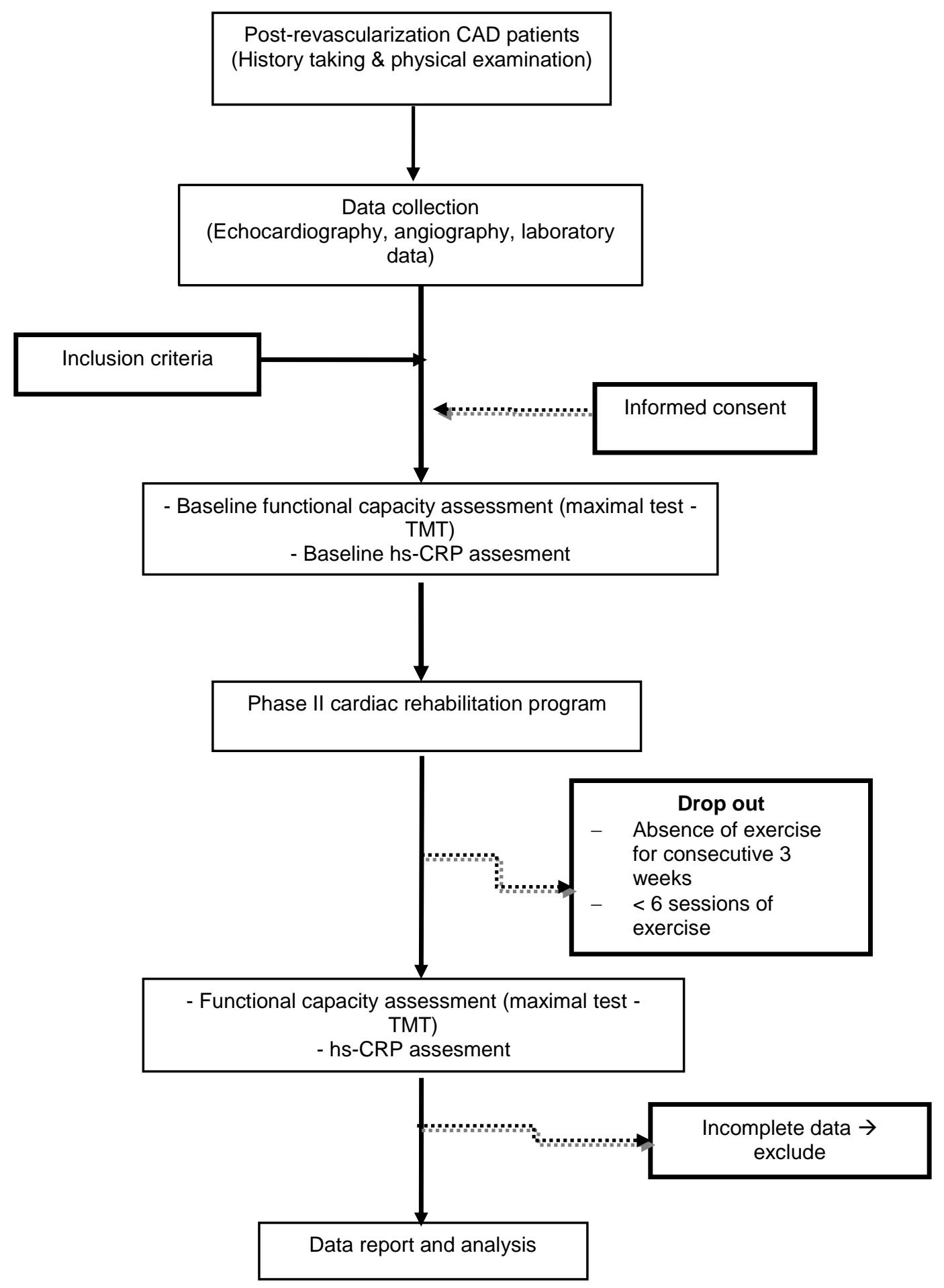

Figure 1. Flow of participants through the trial $\mathrm{CAD}=$ coronary artery disease, $\mathrm{TMT}=$ treadmill test, hs-CRP $=$ high sensitive $\mathrm{C}$-Reactive Protein 
Table 1. Baseline characteristics of participants

\begin{tabular}{lcc}
\hline \multicolumn{1}{c}{ Variables } & $\mathbf{n}$ & $\%$ \\
\hline Age (years, mean \pm SD ) & $56.05 \pm 7.3$ & \\
Gender & & \\
$\quad$ Male & 30 & 81.1 \\
$\quad$ Female & 7 & 18.9 \\
Level of education & & \\
$\quad$ S Senior high school & 11 & 29.7 \\
$\quad$ S Senior high school & 26 & 70.3 \\
Risk factor & & \\
BMI (kg. m-2, mean $\pm S D)$ & $25.32 \pm 2.6$ & \\
Diabetes mellitus & 5 & 13.5 \\
Hypertension & 22 & 59.5 \\
Dyslipidemia & 26 & 70.3 \\
Family history & 11 & 29.7 \\
Smoking & 28 & 75.7 \\
Angiography result & & \\
CAD 1 VD & 11 & 29.7 \\
CAD 2 VD & 12 & 32.4 \\
CAD 3 VD & 14 & 37.8 \\
Ejection Fraction & & \\
$>40 \%$ & 33 & 89.2 \\
S40\% & 4 & 10.8 \\
Procedure & & \\
PCl & 29 & 78.4 \\
Acute coronary syndrome & 20 & 54.1 \\
Elective PCl & 9 & 24.3 \\
CABG & 8 & 21.6 \\
\hline
\end{tabular}

$\mathrm{BMI}=$ body mass index; $\mathrm{CAD}=$ coronary artery disease $; \mathrm{VD}=$ vessel disease $; \mathrm{PCl}=$ percutaneous coronary intervention; $\mathrm{CABG}=$ coronary artery bypass graft

Mean of body mass index (BMI) was $25.32 \mathrm{~kg} / \mathrm{m}^{2}$ and classified as overweight. $^{23}$ Subjects with diabetes mellitus (DM), hypertension, dyslipidemia, family history and smoking history were $13.5 \%, 59.5 \%$, $70.3 \%, 29.7 \%$, and $75.7 \%$ consecutively. Our coronary angiography profile revealed $37.8 \%$ patients had three vessel CAD. Furthermore, most of subjects $(89.2 \%)$ had preserved ejection fraction (EF $>40 \%$ ) and $78.4 \%$ of subjects underwent for $\mathrm{PCl}$. Meanwhile, $21.6 \%$ of subjects underwent CABG for a revascularization procedure (Table 1). Functional Capacity Improvement

Our study found significant improvement in FC from $6.76 \pm 1.94$ to
8.68 \pm 1.60 METs $(p<0.001)$, with a difference of 1.92 METs after completed this CR program. The median of METs differences was 1.68 METs. Then, we analyzed FC improvement related factors. Our bivariate analysis showed age, gender, diabetes mellitus, hypertension, dyslipidemia, smoking history, and type of procedure were not associated with FC level improvement after completed CR program. However, the EF had a low negative correlation $\left(r_{s}=-0.358\right.$, $\mathrm{p}=0.030$ ), baseline FC had a moderate negative correlation $\left(r_{s}=-0.552\right.$, $\mathrm{p}<0.001)$, and baseline hs-CRP level had a lowpositive correlation $\left(r_{s}=0.461\right.$, $\mathrm{p}=0.004$ ) with $\mathrm{FC}$ improvement (Table 2). 

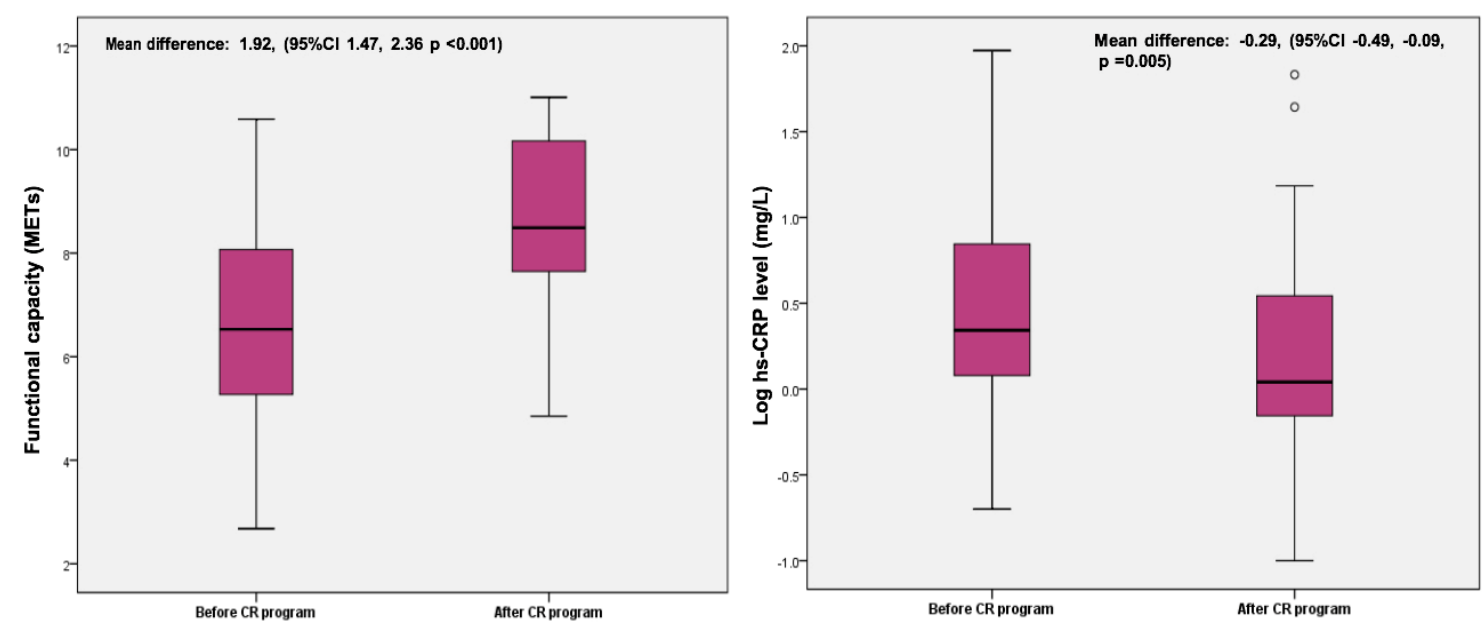

Figure 2. Improvement in functional capacity and in log hs-CRPlevel after CR program

Table 2. Correlation of baseline characteristics, echocardiographic and laboratory parameters with functional capacity improvement and hs-CRP reduction

\begin{tabular}{|c|c|c|}
\hline & $\begin{array}{l}\text { Functional capacity } \\
\text { improvement }\end{array}$ & hs-CRP reduction \\
\hline $\operatorname{Age}^{\$+}$ & $r=-0.051, p=0.763$ & $r_{s}=-0.096, p=0.560$ \\
\hline $\mathrm{BMI}^{\$}$ & $r=-0.044, p=0.797$ & $r_{s}=-0.036, p=0.831$ \\
\hline Ejection fraction ${ }^{\&}$ & $r_{s}=-0,358, p=0.030$ & $r_{s}=-0.272, p=0.104$ \\
\hline Baseline FC level $^{\$}$ & $r=-0.552, p<0.001$ & $r_{s}=-0.383, p=0.019$ \\
\hline Baseline hs-CRP level $^{\&}$ & $r_{S}=0.461, p=0.004$ & $r_{s}=0.724, p=<0.001$ \\
\hline Gender $^{\%}$ & $p=0.329$ & $\mathrm{p}=0.727$ \\
\hline Diabetes mellitus $\%$ & $\mathrm{p}=0.531$ & $\mathrm{p}=0.213$ \\
\hline Hypertension $\%$ & $p=0.950$ & $p=0.567$ \\
\hline Dyslipidemia $\%$ & $p=0.671$ & $\mathrm{p}=0.135$ \\
\hline Smoking \% & $\mathrm{p}=0.205$ & $p=0.357$ \\
\hline Type of procedure $\%$ & $\mathrm{p}=0.058$ & $p=0.001$ \\
\hline
\end{tabular}

${ }^{\$}$ Pearson's correlation; ${ }^{\&}$ Spearman's correlation; \%Mann-Whitney U test +Logarithmic transformation was used to normalize the data

There was an association between baseline FC and FC improvement after adjusting for confounders (Table 3). Patient with 1 METs lower of baseline FC will obtain functional capacity improvement of 0.401 higher after CR. Baseline hs-CRP has a tendency to predict FC improvement. However, in model 1 adjustment, this relation was not significant (Table 3 ). We suggest age or gender is a strong confounder interrupted baseline hs-CRP effect towards FC improvement. Linear regression analysis also showed ejection fraction was not a significant predictor of FC improvement.

\section{Hs-CRP Reduction}

Fourteen patients $(37.8 \%)$ had high baseline of hs-CRP level (>3 $\mathrm{mg} / \mathrm{L}$ ). Hs-CRP level was also reduced significantly after completion of $\mathrm{CR}$ program ( $p=0.005)$. A total of 29 subjects $(78.4 \%)$ had a hs-CRP reduction (mean log baseline of hsCRP was $0.49 \mathrm{mg} / \mathrm{L}$ reduced to 0.20 $\mathrm{mg} / \mathrm{L})$, with difference $0.29 \mathrm{mg} / \mathrm{L}$ $(59.2 \%)$ of log hs-CRP level (Figure 2). 
There was a significant difference in hs-CRP reduction between two types of procedure. Baseline FC level and baseline hs-CRP were lowly and highly correlated with hs-CRP reduction, respectively. After adjusting for baseline FC and other confounders, there was association between baseline hs-CRP level and hs-CRP reduction (Table 4). Patient with $1 \mathrm{mg} / \mathrm{L}$ higher of baseline hs-CRP on average would obtain hs-CRP reduction of $0.877 \mathrm{mg} / \mathrm{L}$ higher after CR. However, baseline FC and type of procedure were not significant predictors for hs-CRP reduction.

Hs-CRP natural course of reduction was considered not interrupt our hs-CRP assessment in this study. Based on available data, we initiate CR program within 14 (8-35) days after procedure. While, hs-CRP reduction was started after first week and back to normal one month after $\mathrm{PCl}$ or major surgery. ${ }^{24,25}$

In purpose to confirm hs-CRP level reduction due to exercise effect instead of type of cases or time related hs-CRP reduction, we compared hsCRP level between the theoretically higher hs-CRP cases $(\mathrm{PCl}$ in acute coronary syndrome case and CABG groups) and the elective $\mathrm{PCl}$ group. Based on independent $T$ test, there were no significant difference in log baseline hs-CRP $(P=0.176)$ and log hsCRP reduction $(P=0.728)$ between two groups.

If we compare between $\mathrm{PCl}$ and CABG groups. There were significant difference in log baseline hs-CRP $(P=0.007)$ and log hs-CRP level reduction $(P=0.003)$ between two groups. However, there was significant log hs-CRP reduction between pre and post CR program in evey subgroup of cases (CABG and $\mathrm{PCl}$ group). It may propose positive confirmation of our hypothesis that hs-CRP level reduction caused by CR program independent of type of procedure and hs-CRP reduction related time. In this study, hsCRP reduction have a high probability caused by phase II CR program.

\section{Association of FC and hs-CRP Improvement}

There was moderate correlation $\left(r_{s}=0.636, \quad p<0.001\right)$ between FC improvement and hs-CRP reduction. Furthermore, FC improvement can predict hs-CRP level reduction. Each 1 METs improvement after CR program can reduce $9.317 \mathrm{mg} / \mathrm{L}$ of transformed hs-CRP level $\quad(p=0.006,95 \% \mathrm{Cl}$ $2.942,15.693)$

\section{DISCUSSION}

Our baseline characteristic showed $70.3 \%$ subjects had good level of education (completed senior high school). This characteristic was favorable to this study since education was an important element for rehabilitation program compliance and it could be reflected in small number of drop out patient in the study. ${ }^{27} \mathrm{We}$ initiate CR program earlier; within 2 weeks after procedure. Initiation of CR after 1 week leads to a $90 \%$ increase in participation rates compared to a initiation after 4 weeks. ${ }^{28}$

\section{Functional Capacity Improvement}

This study demonstrated phase II CR program, consisted of hospital gymnasium and home exercise training completed with healthy lifestyle education, could produce significant improvement with an average of 1.92 METs (28.4\%) in FC and this study result was consistent with several previous studies in phase II CR program. Cardiac rehabilitation program improved FC with average of 0.43 METs to 1.46 METs $(9.1 \%$ to $26.8 \%){ }^{13,29-32}$ Our good result in this study could be explained by the low FC baseline of subjects as it might result in significant difference. A CR improve exercise capacity, and may be caused by an adaptive response involved in an increased capacity of endogenous anti oxidative systems or more efficient oxidative metabolites. 

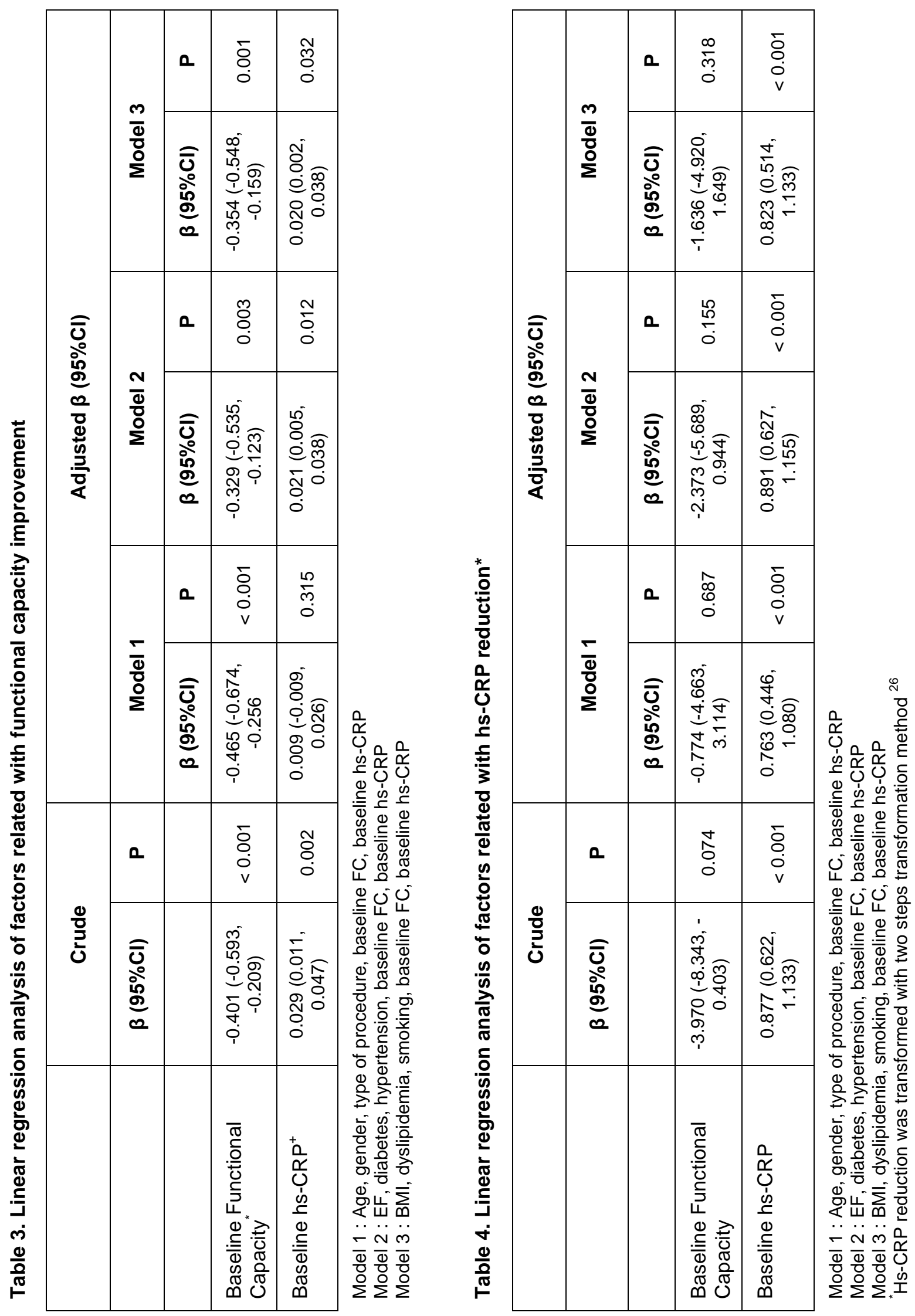
Exercise training rises the capillary density of the skeletal muscle, promotes a transformation from type II to type I muscle fiber, and increases the amount and oxidative enzyme activities of mitochondria. These peripheral mechanisms play significant part in the increase in $\mathrm{VO}_{2}$ max by exercise training. The increase in exercise capacity is also assumed to be caused by myocardial ischemic threshold improvement in patients with CAD. ${ }^{33}$ Diabetes mellitus, hypertension, dyslipidemia, smoking and type of intervention were not associated with FC improvement. The CR program is an excellent measure to improve CAD patients' quality of life and reduce morbidity and mortality. ${ }^{34}$ Different from this study, Branco et al. $^{35}$ showed greater mean functional capacity improvement in age $>45$ years old, non diabetes mellitus and post-CABG patients. Our patients' age characteristic $(97.3 \%)>45$ years old, diabetes mellitus control status and earlier initiation of $\mathrm{CR}$ might lead differences in these findings. Early $\mathrm{CR}$ program will reduce deconditioning period of post-CABG patients and improve FC baseline in post-CABG patients. ${ }^{36}$ Therefore, it might result in no significant difference between post$\mathrm{PCl}$ and CABG patients' post-CR FC improvement. Multivariate analysis demonstrated the baseline FC was the only independent predictors of FC improvement after completion of phase II CR program.

This finding emphasized the phase II CR program be significantly improved FC independent of the presence of CAD risk factors and type of procedure. CR program appeared to give more benefit in a patient with worse condition (low FC level) independent to other factors. Previous studies were consistent with these findings. Shiram et al. $^{37}$ showed initial exercise capacity as the only independent variable predicting improvement in exercise performance after rehabilitation program. Ades et al. ${ }^{38}$ study also showed the baseline physical function score was the only baseline variable that predicted change in physical function score after rehabilitation. Patients with the lowest baseline physical function score were the most likely to show an improvement in physical function score after rehabilitation. ${ }^{38,39}$

Ejection fraction was not an independent predictor of FC improvement in linear regression analysis. This result was consistent with a study performed by Sousa et al. ${ }^{40}$, which demonstrated FC improvement achieved after completion of $\mathrm{CR}$ program was independent of initial left ventricle function. Maximal oxygen intake depends on several parameters, such as ventilation, oxygen diffusion at lung level, peripheral perfusion and diffusion, and mitochondrial function which in several conditions have more important role than oxygen transport by circulation itself. ${ }^{41}$ Both diabetes mellitus and hypertension are common risk factors for CAD. In type 2 diabetes mellitus, a reduction in maximal a- $v \mathrm{O}_{2}$ difference contributes to a decreased VO2 $\max ^{42}$ Endothelial and mitochondrial dysfunction also responsible for lower oxygen consumption in arterial hypertension patients. ${ }^{43}$

\section{hs-CRP Reduction}

Atherosclerosis involves inflammation process, typically depicted in increase of hs-CRP level as a nonspecific inflammatory marker and predictive factor of CAD. ${ }^{14}$ This study showed an average reduction of 0.29 $\mathrm{mg} / \mathrm{L}(59.2 \%)$ in log hs-CRP level after CR program. This result was consistent with other previous studies with average reduction of $0.02-2.10 \mathrm{mg} / \mathrm{L}$ $(1.3-35.6 \%)$ in hs-CRP level. ${ }^{13,15,44}$ One mechanism proposed to explain training's CRP reduction effect is cytokine production reduction by adipose tissue, skeletal muscle, endothelial cells, and blood mononuclear cells. 
Regular muscle movement
during exercise may modify
inflammation locally while systemic
inflammation is reduced through
muscle-derived cytokines. Muscle is
myokine secretory organ and muscle
contraction produces myokines
opposing pro-inflammatory cytokines
and reduce low-grade chronic inflammation. ${ }^{45}$ Exercise training may reduces CRP indirectly by increasing insulin sensitivity, improving endothelial function, and reducing body weight. ${ }^{13,46}$ However, another study conducted by Luk et al. ${ }^{32}$, showed their cardiac rehabilitation training program did not significantly alter the subject's hs-CRP level. The medium baseline of hs-CRP level in that study might cause this finding.

Based on our study, reduction in hs-CRP level after CR program more prominent in higher baseline of hsCRP level. This finding also explained the higher reduction of hs-CRP in this study than previous studies. Statin was not considered to affect our study result since all enrolled patients consumed statin more than one week and hs-CRP decreased significantly after one week of statin treatment (at the time we measured hs-CRP baseline level). ${ }^{47}$ Our study revealed a high hs-CRP reduction $(59.2 \%)$, which might indicate CR program impact on hs-CRP reduction besides the statins. This result consistent with Milani et al. ${ }^{13}$ study which identify benefit of phase II CR training programs to reduce hsCRP with similar or greater effect than statin drugs.

We found baseline hs-CRP was the only significant predictor of hs-CRP reduction after CR program. The antiinflammatory effect of exercise in person with coronary heart disease may be greater because of their higher inflammatory levels. ${ }^{48}$ In Lakka et $\mathrm{al}^{49}$ study with 652 sedentary healthy adult, hs-CRP reduced by $1.34 \mathrm{mg} / \mathrm{L}$ in individuals who had high $(3.0 \mathrm{mg} / \mathrm{L})$ baseline hs-CRP levels, but did not change among those with low (1.0 $\mathrm{mg} / \mathrm{L})$ or moderate (1.0-3.0 $\mathrm{mg} / \mathrm{L})$ baseline hs-CRP levels. The difference in the hs-CRP change among the baseline hs-CRP group was still significant after adjustment for all correlates variables such as body weight, glucose, insulin, LDL, HDL, triglycerides, systolic and diastolic blood pressure, and maximal oxygen uptake. Though there is a tendency of significant correlation between type of procedure and hs-CRP reduction, type of case or procedure was not significant predictor in multivariate analysis. Higher baseline of hs-CRP caused higher hs-CRP level reduction after CR program in CABG group compared to $\mathrm{PCl}$ group. Since most of study of hsCRP in PCl or CABG patients show hsCRP as prognostic marker, we suggest hs-CRP level may not have any clinical association with type of case/procedure, and it more reflected patient's prognosis. ${ }^{50-54}$

Association between FC and hsCRP level is interrelated. Patient with good FC has lower level of hs-CRP and vice versa, patient with lower FC had a higher hs-CRP level. ${ }^{18,55,56}$ Functional capacity improved prognosis mechanism is partly mediated by hsCRP lowering effect. ${ }^{18}$ Furthermore, high hs-CRP itself is a marker for impaired functional capacity. ${ }^{57,58}$ This study found FC improvement positively correlated with hs-CRP reduction after program. The direct mechanism of FC improvement to reduce hs-CRP level is still unknown, and might be explained by exercise related effect to hs-CRP reduction. Our study results were remarkable compared with other previous studies, since the less frequency of our CR program (two times a week). Difficulty in access to CR center, social and administrative problems had been concerns in our setting. However, prescribed home exercise could overcome this condition. In our center, phase II CR program started earlier; in two weeks after procedure despite in most of previous $\mathrm{CR}$ studies, the programs were 
initialized four weeks after revascularization procedure. In our setting, earlier CR program was needed to be performed since our culture of post-myocardial infarct or revascularization patients frequently lead to sedentary lifestyle.

\section{Limitations}

There are several limitations in this study. Firstly, cardiopulmonary exercise test with respiratory gas analysis (CPX) was not used as a gold standard of $\mathrm{VO}_{2}$ max calculation in $\mathrm{FC}$ measurement. ${ }^{19,59}$ Equipment costs limited direct $\mathrm{VO}_{2}$ max measurement in this study. Secondly, control group was not involved in this study as a comparison of non-intervention group. Control group would give more benefit data for FC difference and hs-CRP reduction after intervention. Thirdly, supervision and documentation of patient's home exercise activity were not conducted. Home prescribed exercise during CR phase II documentation might add more data for its effect in functional capacity improvement. Lastly, there is still a possibility for drugs combination, such as statin, angiotensin converting enzyme (ACE)-inhibitors, angiotensin receptor blockers (ARBs) and beta blockers (BBs) to bring attenuation effect on hs-CRP level. Another study could be performed by putting these limitations into account. Our finding of association between FC improvement and hs-CRP level reduction can be a hypothesis for the next study to show FC only surrogate marker in patient clinical improvement and clinical improvement can be caused by hs-CRP reduction.

In conclusion, phase II CR program significantly increased FC and reduce hs-CRP level in postrevascularization $\mathrm{CAD}$ patient, and more prominent in patient with low baseline FC and high hs-CRP level. The FC improvement and hs-CRP reduction were moderately correlated.

\section{Conflict of Interest}

The authors declare that is no conflict of interest.

\section{Funding}

This research was funded by internal research grant of Universitas Padjadjaran.

\section{REFERENCES}

1. Montalescot G., Sechtem U., Achenbach S., Andreotti F., Arden C., Budaj A., et al. 2013. 2013 ESC guidelines on the management of stable coronary artery disease: the Task Force on the management of stable coronary artery disease of the European Society of Cardiology. Eur Heart J, 34(38):2949-3003.

2. Badan Penelitian dan Pengembangan Kesehatan. 2013. Riset Kesehatan Dasar (RISKESDAS) 2013. Lap Nas 2013, 1-384.

3. Reddy K.S., Yusuf S. 1998. Emerging epidemic of cardiovascular disease in developing countries. Circulation, 97(6):596-601.

4. Sanchis-Gomar F., Perez-Quilis C., Leischik R., Lucia A. 2016. Epidemiology of coronary heart disease and acute coronary syndrome. Ann Transl Med, 4(13):256.

5. Khera R., Jain S., Pandey A., Agusala V., Kumbhani D.J., Das S.R., et al. 2017. Comparison of readmission rates after acute myocardial infarction in 3 patient age groups (18 to 44,45 to 64 , and $\geq 65$ Years) in the United States. Am J Cardiol, 120(10):1761-1777.

6. Venturini E., Testa R. 2014. Cardiac rehabilitation and percutaneous coronary intervention: together against global burden of cardiovascular 
disease. J Cardiol Ther, 1(1).

7. Lee H.Y., Kim J.H., Kim B.O., Byun Y.S., Cho S., Goh C.W., et al. 2013. Regular exercise training reduces coronary restenosis after percutaneous coronary intervention in patients with acute myocardial infarction. Int J Cardiol, 167(6):2617-2622.

8. Myers J., Prakash M., Froelicher V., Do D., Partington S., Atwood J.E. 2002. Exercise capacity and mortality among men referred for exercise testing. $\mathrm{N}$ Engl J Med, 346(11):793-801.

9. Ross R. 1999. Atherosclerosisan inflammatory disease. $\mathrm{N} \mathrm{Engl}$ J Med, 340(2):115-126.

10. Ridker PM. 2003. Clinical application of c-reactive protein for cardiovascular disease detection and prevention. Circulation, 107(3):363-369.

11. Hansson G.K. 2005. Inflammation, atherosclerosis and coronary artery disease. N Engl J Med, 352(16):16851695.

12. Morrow D.A., Braunwald E. 2003. Future of biomarkers in acute coronary syndromes: moving toward a multimarker strategy. Circulation, 108(3):250-252.

13. Milani R.V., Lavie C.J., Mehra M.R. 2004. Reduction in Creactive protein through cardiac rehabilitation and exercise training. J Am Coll Cardiol, 43(6):1056-1061.

14. Ridker P.M. 2001. Highsensitivity c-reactive protein: potential adjunct for global risk assessment in the primary prevention of cardiovascular disease. Circulation, 103(13):1813-1818.

15. Keating F.K., Schneider D.J., Savage P.D., Bunn J.Y., Harvey-Berino J., Ludlow M., et al. 2013. Effect of exercise training and weight loss on platelet reactivity in overweight patients with coronary artery disease. J Cardiopulm Rehabil Prev. 33(6):371-377.

16. Aronson D., Sheikh-Ahmad M., Avizohar O., Kerner A., Sella R., Bartha P., et al. 2004. C-

Reactive protein is inversely related to physical fitness in middle-aged subjects.

Atherosclerosis, 176(1):173179.

17. Church T.S., Barlow C.E., Earnest C.P., Kampert J.B., Priest E.L., Blair S.N. 2002. Associations between cardiorespiratory fitness and Creactive protein in men. Arterioscler Thromb Vasc Biol, 22(11):1869-1876.

18. Nunes R.A.B, Araújo F., Correia G.F., Da Silva G.T., Mansur A.J. 2013. High-sensitivity C-reactive protein levels and treadmill exercise test responses in men and women without overt heart disease. Exp Clin Cardiol, 18(2):124-128.

19. Mezzani A., Hamm L.F., Jones A.M., McBride P.E., Moholdt T., Stone J.A., et al. 2012. Aerobic exercise intensity assessment and prescription in cardiac rehabilitation: a joint position statement of the European Association for Cardiovascular Prevention and Rehabilitation, the American Association of Cardiovascular and Pulmonary Rehabilitat. Eur J Prev Cardiol, 20(3):442-467.

20. Giannuzzi P., Saner H., Björnstad H., Fioretti P., Mendes M., Cohen-Solal A., et al. 2003. Secondary prevention through cardiac rehabilitation: position paper of the Working Group on Cardiac Rehabilitation and Exercise Physiology of the European Society of Cardiology. Eur Heart J, 24(13):1273-1278.

21. Balady G.J., Williams M.A., Ades P.A., Bittner V., Comoss P., Foody J.M., et al. 2007. Core 
components of cardiac rehabilitation/secondary

prevention programs: 2007 update: a scientific statement from the American Heart Association Exercise, Cardiac Rehabilitation, and Prevention Committee, the Council on Clinical Cardiology; the Councils o. Circulation. 115(20):26752682.

22. Smit J.J., Ottervanger J.P., Slingerland R.J., Kolkman J.J., Suryapranata H., Hoorntje J.C., et al. 2008. Comparison of usefulness of C-reactive protein versus white blood cell count to predict outcome after primary percutaneous coronary intervention for ST elevation myocardial infarction. Am J Cardiol, 101(4):446-451.

23. Word Heatlh Organization. 2017. BMI Classification. WHO. Available from: http://apps.who.int/bmi/index.jsp ?introPage=intro_3.html

24. Kunakornsawat S., Tungsiripat R., Putthiwara D., Piyakulkaew C., Pluemvitayaporn T., Pruttikul P., et al. 2017. Postoperative kinetics of C-reactive protein and erythrocyte sediment rate in one-, two-, and multilevel posterior spinal decompressions and instrumentations. Glob Spine J. 7(5): 448-451.

25. Ørn S., Manhenke C., Ueland T., Dams J.K., Mollnes T.E., Edvardsen T., et al. 2009. Creactive protein, infarct size, microvascular obstruction, and left-ventricular remodelling following acute myocardial infarction. Eur Heart J, 30(10):1180-1186.

26.Templeton G.F. 2011. A two-step approach for transforming continuous variables to normal: Implications and recommendations for IS research. Commun Assoc Inf Syst, 28(1):41-58.
27. Ramm C., Robinson S., Lecturer S., Sharpe N. 2001. Factors determining non-attendance at a cardiac rehabilitation programme following myocardial infarction. N Z Med J, :19951997.

28. Haykowsky M., Scott J., Esch B., Schopflocher D., Myers J., Paterson I., et al. 2011. A Metaanalysis of the effects of exercise training on left ventricular remodeling following myocardial infarction: start early and go longer for greatest exercise benefits on remodeling. Trials, 12: 92.

29. Cornelissen V.A., Onkelinx S., Goetschalckx K., Thomaes T., Janssens S., Fagard R., et al. 2014. Exercise-based cardiac rehabilitation improves endothelial function assessed by flow-mediated dilation but not by pulse amplitude tonometry. Eur J Prev Cardiol, 21(1):39-48.

30. Belardinelli R., Paolini I., Cianci G., Piva R., Georgiou D., Purcaro A. 2001. Exercise training intervention after coronary angioplasty: The ETICA trial. J Am Coll Cardiol, 37(7):1891-1900.

31. Kim Y.J., Shin Y.O., Bae J.S., Lee J.B., Ham J.H., Son Y.J., et al. 2008. Beneficial effects of cardiac rehabilitation and exercise after percutaneous coronary intervention on hsCRP and inflammatory cytokines in CAD patients. Pflügers Arch Eur J Physiol, 455(6):1081-1088.

32. Luk T.H., Dai Y.L., Siu C.W., Yiu K.H., Chan H.T., Lee S.W., et al. 2012. Effect of exercise training on vascular endothelial function in patients with stable coronary artery disease: a randomized controlled trial. Eur J Prev Cardiol, 19(4):830-839.

33. JCS Joint Working Group. 2014. Guidelines for rehabilitation in patients with cardiovascular 
disease (JCS 2012). Circ J, 78(8):2022-2093.

34. Mampuya W.M. 2012. Cardiac rehabilitation past, present and future: an overview. Cardiovasc Diagn Ther, 2(1):38-49.

35. Branco C., Viamonte S., Matos C., Magalhães S., Cunha I., Barreira A., et al. 2016. Predictors of changes in functional capacity on a cardiac rehabilitation program. Rev Port Cardiol (English), 35 35(4):215224.

36. Niebauer J. 2016. Treatment after coronary artery bypass surgery remains incomplete without rehabilitation. Circulation, 133(24):2529-2537.

37. Shiran A., Kornfeld S., Zur S., Laor A., Karelitz Y., Militianu A., et al. 1997. Determinants of improvement in exercise capacity in patients undergoing cardiac rehabilitation. Cardiology, 88(2):207-213.

38. Ades P.A., Maloney A., Savage P., Carhart R.L.Jr. 1999. Determinants of physical functioning in coronary patients: response to cardiac rehabilitation. Arch Intern Med, 159(19):2357-2360.

39. Martin B.J, Arena R., Haykowsky M., Hauer T., Austford L.D., Knudtson M., et al. 2013. Cardiovascular fitness and mortality after contemporary cardiac rehabilitation. Mayo Clin Proc, 88(5):455-463.

40. Sousa C., Rocha A., Rangel I., Goncalves A., Melao F., Rodrigues J., et al. 2013. Functional capacity benefits of cardiac rehabilitation after acute coronary syndrome are sustained in time and independent of left ventricle systolic function. Eur $\mathrm{J}$ Heart Fail, 12:S166.

41. Myers J., Froelicher V.F. 1991. Hemodynamic determinants of exercise capacity in chronic heart failure. Ann Intern Med,115(5):377-386.

42. Baldi J.C., Aoina J.L., Oxenham H.C., Bagg W., Doughty R.N. 2003. Reduced exercise arteriovenous $\mathrm{O} 2$ difference in type 2 diabetes. J Appl Physiol, 94(3):1033-1038.

43. Tadic M., Ivanovic B. 2014. Why is functional capacity decreased in hypertensive patients? from mechanisms to clinical studies. J Cardiovasc Med (Hagerstown), 15(6):447-455. .

44. Astengo M., Dahl A., Karlsson T., Mattsson-Hultén L., Wiklund O., Wennerblom B. 2010. Physical training after percutaneous coronary intervention in patients with stable angina: effects on working capacity, metabolism, and markers of inflammation. Eur J Cardiovasc Prev Rehabil, 17(3):349-354.

45. Pedersen B.K., Febbraio M.A. 2012. Muscles, exercise and obesity: Skeletal muscle as a secretory organ. Nat Rev Endocrinol, 8(8):457-465.

46. Kasapis C., Thompson P.D. 2005. The effects of physical activity on serum C-reactive protein and inflammatory markers: A systematic review. J Am Coll Cardiol, 45(10):15631569.

47. Ansell B.J., Watson K.E., Weiss R.E., Fonarow G.C. 2003. hsCRP and HDL effects of statins trial (CHEST): rapid effect of statin therapy on Creactive protein and high-density lipoprotein levels A clinical investigation. Heart Dis, 5(1):27.

48. Nicklas B.J., Hsu F.C., Brinkley T.J., Church T., Goodpaster B.H., Kritchevsky S.B., et al. 2008. Exercise training and plasma C-reactive protein and interleukin-6 in elderly people. J Am Geriatr Soc, 56(11):2045 - 
2052.

49. Lakka T.A., Lakka H.M., Rankinen T., Leon A.S., Rao D.C., Skinner J.S., et al. 2005. Effect of exercise training on plasma levels of C-reactive protein in healthy adults: The HERITAGE Family Study. Eur Heart J, 26(19):2018-2025.

50. Ribeiro D.R.P., Ramos A.M., Vieira P.L., Menti E., Bordin O.L.Jr., Souza P.A., et al. 2014. High-sensitivity C-reactive protein as a predictor of cardiovascular events after STelevation myocardial infarction. Arq Bras Cardiol, 103(1): 69-75.

51. Kishk Y.T., Youssef A.A., Bafadhl T.A. 2012. Prognostic significance of high sensitivity $\mathrm{C}$ reactive protein in patients with angina pectoris underwent percutaneous coronary intervention. J Saudi Hear Assoc, 24(4):299-302.

52. Rahel B.M., Visseren F.L.J., Suttorp M.J., Plokker T.H.W., Kelder J.C., De Jongh B.M., et al. 2003. Preprocedural serum levels of acute-phase reactants and prognosis after percutaneous coronary intervention. Cardiovasc Res, 60(1):136-140

53. Balciunas M., Bagdonaite L., Samalavicius R., Griskevicius L., Vuylsteke A. 2009. Preoperative high sensitive Creactive protein predicts cardiovascular events after coronary artery bypass grafting surgery: a prospective observational study. Ann Card Anaesth, 12:127-132.

54. Owens C.D., Ridker P.M., Belkin M., Hamdan A.D., Pomposelli
F., Logerfo F., et al. 2007. Elevated C-reactive protein levels are associated with postoperative events in patients undergoing lower extremity vein bypass surgery. J Vasc Surg, 45(1):2-9.

55. Jae S.Y., Heffernan K.S., Yoon E.S., Lee M.K., Fernhall B., Park W.H. 2009. The inverse association between cardiorespiratory fitness and Creactive protein is mediated by autonomic function: a possible role of the cholinergic antiinflammatory pathway. Mol Med, 15(9-10): 291-296.

56. Rahimi K., Secknus M.A., Adam M., Hayerizadeh B.F., Fiedler M., Thiery J., et al. 2005. Correlation of exercise capacity with high-sensitive C-reactive protein in patients with stable coronary artery disease. Am Heart J, 150(6):1282-1289.

57. Broekhuizen R., Wouters E.F.M., Creutzberg E.C., Schols A.M. 2006. Raised CRP levels mark metabolic and functional impairment in advanced COPD. Thorax, 61(1):17-22.

58. Radenovic S., Loncar G., Busjahn A., Apostolovic S., Zdravkovic M., Karlicic V., et al. 2018. Systemic inflammation and functional capacity in elderly heart failure patients. Clin Res Cardiol, 107(4):362-367.

59. Koutlianos N., Dimitros E., Metaxas T., Deligiannis A.S., Kouidi E. 2013. Indirect estimation of $\mathrm{VO} 2$ max in athletes by ACSM's equation: Valid or not? Hippokratia, 17(2):136-140. 